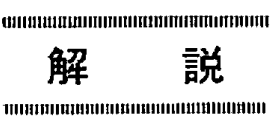

UDC $669.184 .244 .66: 541.124: 669.046 .541 .58$

\title{
LD 転炉製鋼プロセスの動力学*
}

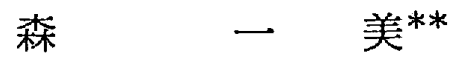

\section{Kinetics of Steelmaking Processes in the Basic Oxygen Converter}

\section{Kazumi MORI}

\section{1. 緒言}

L D 転炉製鋼の特徵は, 吹鍊が急速であり，しが $\mathrm{P}$ やNなど不純物の少ない銅が溶製されることである：こ れを可能にしている师内反応の機構の解明については従 来多くの研究が行なわれてきた. 一方実際の転炉製鋼技 術には幾多の改善進歩がなされてきたが，プロセスコン トロールの上でなお問題があり，今後の製鋼技術の発展 のために炉内の反応機構の解明はさらにおし進めてゆく ことが必要である。

本稿は，転炉製鋼プロセスの動力学的な䦗題のうち； 炉内の状況や吹錬反応の機構について，なるべく最近の 文献をもとにして解説したものである，とくに，叔内反 応を考光るときの基本になる問題に重点をおいたもので 炉内の個々の反応の詳細な機構にはふれていない†.

\section{2. 炉内の状況}

転炉吹錬中の各成分濃度の時間変化は転炉内の状況を 端的に表わすもので，これについては従来多くの研究が 行なわれてきた。代表的な例を図 1 に示す4). 図のよう な濃度の時間変化については, 数式モデルによる説明は 行なわれているが5)6), 反応の具体的な機構との関連で不 明稚な点が多々ある. 帄内の状況は複雑であり, 鋼浴や スラグが図1で表わされる均一な組成をもつているかど うか多分に問題があり，また反応機侢を解明するための 炉内状沅の把握に沈化学的因子の添か物理的な面加ら む検討を加えることが必要である. 以下炉内各部の状況 について述へる。

\section{1 火点}

酸素シェットが鋼浴に衝突する“火点”は炬内プロセ スの起点になるすのである. 従来火点の面積あるいはく ほ夕深さにつき，流体力学にもとづ理論式やコールド モデルによる実験式をるとにした推定が行なわれてきた が，FLINN らてはくぼみ深さを実際の吹錬状態において 観察した，帄は $100 \mathrm{lb}, 300 \mathrm{lb}$ および $400 \mathrm{lb}$ で，観察

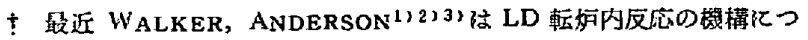
いて包括的な解説な行なつている.

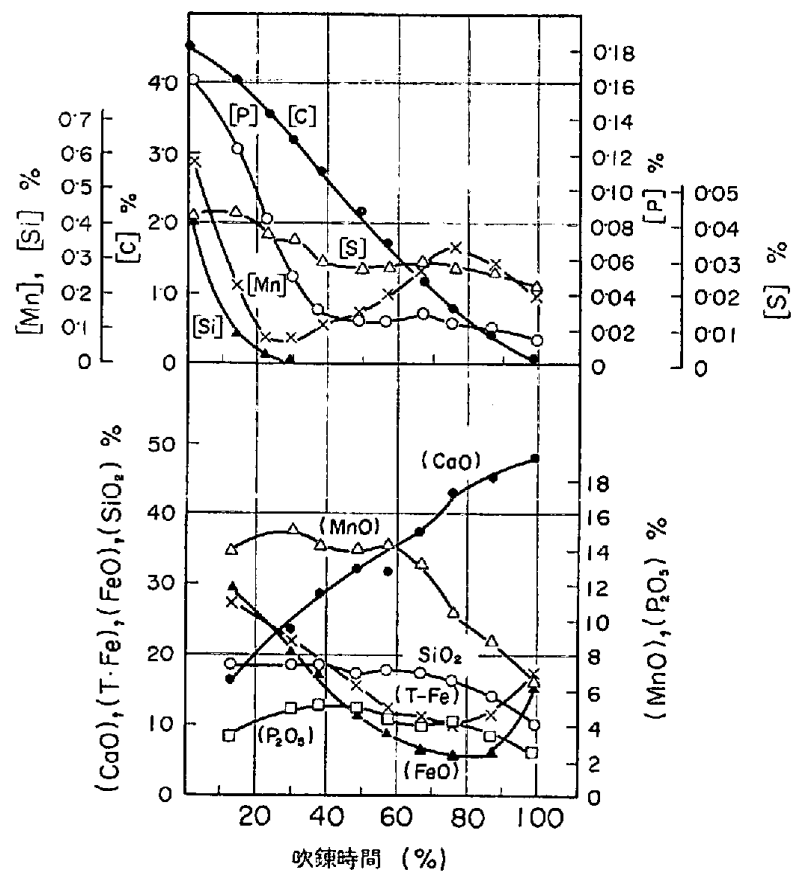

図 1 吹錬中の鋼浴扎よびスラグ成分の濃度变化 (二上，松田，小谷野，安居 ${ }^{4)}$ )

はつぎの 4 通りの方法を用いて行なつた。

1) 底部に細いノ゙ルを probeとして埋めておき，咥 素を気泡として吹込み，酸素シェットの底部到達による probe 内の圧力の変動からくぼみ深さを求める

2) 底部の侵食状態

3）底部の小孔からのジェット噴出あるいは溶鋼の流 出の観察

4) ランス通しての火点部の光学的観察

図 2 は1)，2）の方法で得られた結果を比較したもので ある・両者はよく一致しており，くぼみ深さは $P_{d} D_{t} / \sqrt{H}$

$\left(P_{d}\right.$ : 酸素仕-psia, $D_{t}:$ ノズル径-inch, $H$ : ノズル高 さ-inch) で表わされるジェットの強さで一義的にきま ることがわかつた、なお図 2 のくほみ深さは往来モデル

* 昭和 49 年 2 月 7 日受付（依頼解説）

** 名古屋大学工学部 工博 


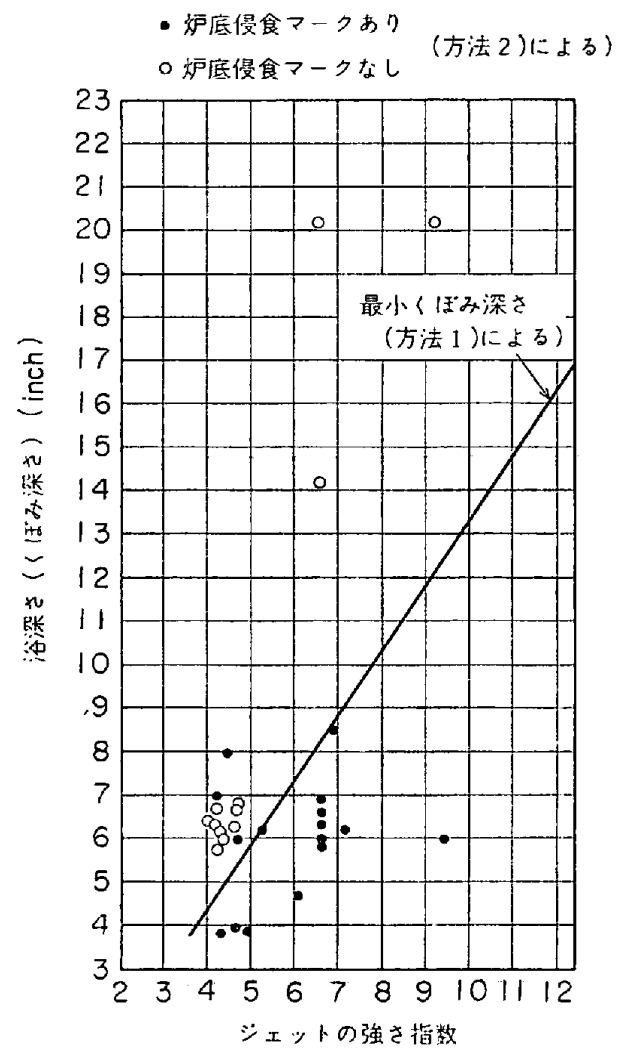

因 2 火点におけるくほみ深さ (Flinn, Pehlke, Glass, Hays ${ }^{7)}$ )

実験から推定されてきた値8)にかなり近いことが示され る. 火点のくぼみについては従来は必ずしも十分な確証 がなかつたが，以上のような結果が得られたことは転炉 の炉内状況を把握するうえで大きなよりどころになると 考える.

シェットのもつ特性は雲囲気の盜度に大きく影響さ れ，霑囲気が高温になるほど鋼浴のくぼみ媣さが大にな ることが伊東，鞭りによる理論解析から予想されたが，

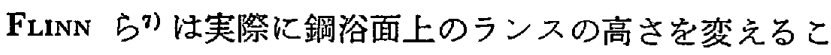
とによりジェットにをきこまれる零囲気の温度を变化さ せ impact pressure を測定し，伊東らの予想したような 雲囲気の影響を確かめている。

\section{2 鋼浴内の揌拌}

転炉内の鋼浴は酸素ジェットおよび $\mathrm{CO}$ 気泡生成浮上 のエネルギーにより強力に摫拌されるが，この攪捧の強 さや湯動きの方向は炬内反応の機構を検討する場合には しばしば問題になる。これについて従来常温のモデル実 験が行なわれ，図3(a) のような流れのあることが推定 されてきたが実証はなかつたＦLINN ら7および ROTE ら ${ }^{10)}$ は実験炬でこの問題を検討している.

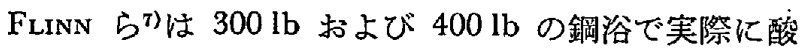
素を吹付けた状態で黒鉛の rudder（方向舵）を用い湯動 きの方向を調べた. その結果, 中心では上方へ, 表面で は半径方向, そして周囲の壁部に沿つて下方への流れが

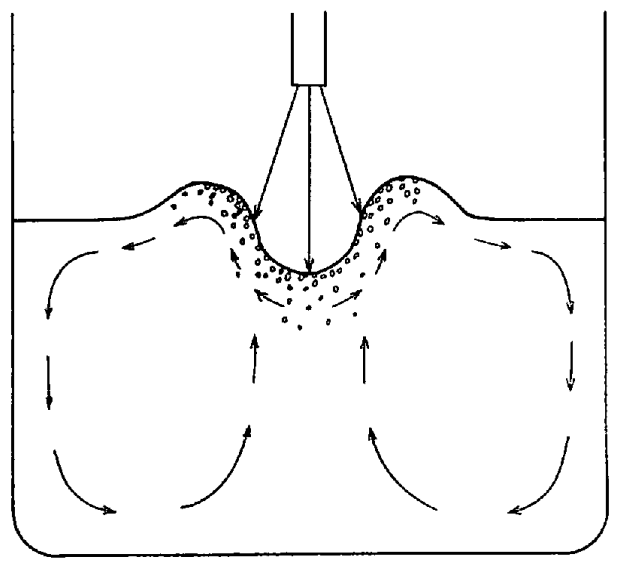

(a)

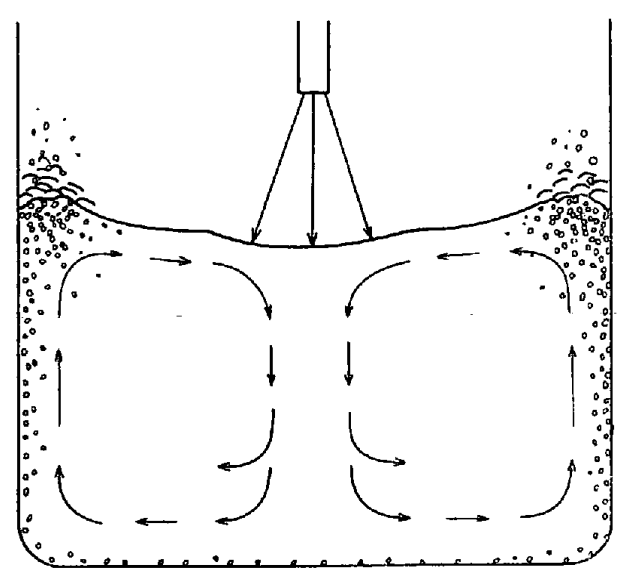

(b)

図 3 吹鍊中の鋼浴の動き

あることを見い出している. 同様な結論はROTE ら ${ }^{10}$ に より浴内の組成の不均一を分布状態加ら得られてい る. これについては後述する.

湯動きについててれと対立するような見解がCHIPMAN 11)により公表されている.これは鋼浴 $30 \mathrm{t}$ の炻による 実験で，炉中に耐熱性の板を溶接した rudder をいれ， 吹鍊中の rudder の向く方向から図 $3(\mathrm{~b})$ のような流れ があるとしている.

鋼浴内の流れについてこのように異なつた結果が得ら れていることは, 詳細は不明であるが，一応つきのこと が考えられる. 浴の攪汼はシェットの強さと $\mathrm{CO}$ 気泡生 成の強さによるが，気泡生成が主として火点近傍でおこ る場合と浴内全域あるいは师壁でおこる場合とでは湯の 動きが大い供なることが考えられる. 図 3 (b)のよう な流れは, ジェットの強さが比較的弱く $\mathrm{CO}$ 気泡が鋼浴 全体で発生し，これによる㹂拌力が浴全体の動きを支配 するような場合におこるものと考える. しかし通常の吹 錬においては脱炭は主として火点近傍でおこり, 浴全体 の動きは火点部におけるはげしい動きにより支配され， 因 3 (a)のような動きがでてくるるのと思われる. 


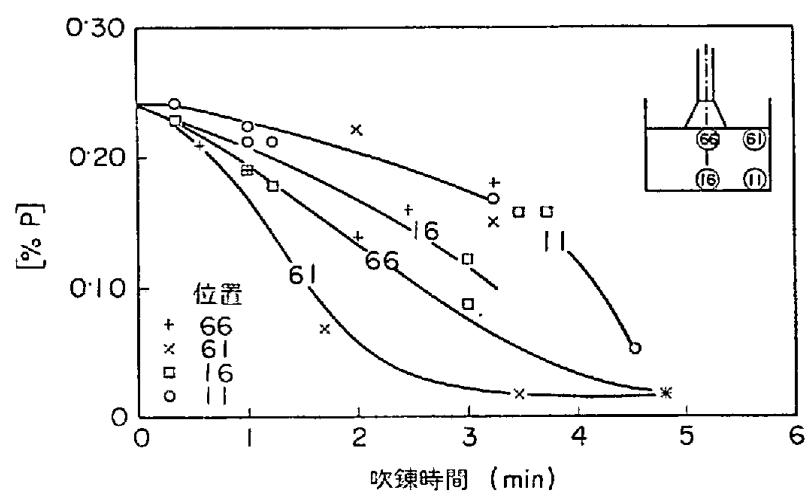

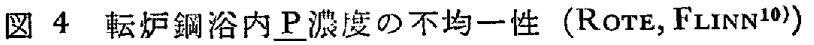

\section{$2 \cdot 3$ 鋼浴内の濃度および温度の不均一性}

鋼浴内の諸成分の濃度や温度の不均一性は反応の dynamic control の上できわめて重要である.これにつ いて RoTE ら ${ }^{10}$ は $300 \mathrm{lb}$ の実験炉で側壁を通しての試 料採取による調查検討を行なつた. 図4 亿その1例とし て浴内の各部における卫濃度の变化を示した。これでわ かるように，浴内の浱度の不均一性はいちじるしく，表 面近くで $\mathrm{P} 0.02 \%$ 程度の場合，下部は $\mathrm{P} 0.05 \sim 0.10 \%$

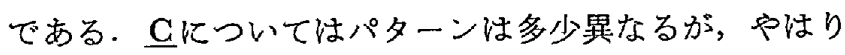
下部のほうが濃度が高い，乙れらの結果は図 3(a)の掜 找パターンで説明され，鋼浴全体としての動きは必ずし む強くないことを示すむのである。

ROTE ら ${ }^{10)}$ はた，側壁を通した熱電対による温度測 定を行ない，温度もまた不均一分布をしていることを見 いだしている.これによれば温度は(11)（図4）の位置が むつとも低く，これは鋼浴が側壁を上向きに流れるとい う図 3(b)のパターンでは説明できない。

\section{4 スラグーメタルエマルジョン層について}

転炬内のスラグ層は，溶融スラグ，未消化の石灰，気 泡，および粒鉄の 4 相からなるエマルジョン層であり， この層の挙動が溶鋼中諸成分の浱度変化やスロッピング に微妙に影響する ${ }^{22}$. この層は普通スラク゚ーメタルエマ ルション層，あるいは泡立ちスラグ層と呼ばれる。

このエマルション層の生成や安定性は, スラグの性状 と CO 気泡生成によるが，これについては KozAKEVITCH ${ }^{13)}$ の詳細な解説がある. また, 脱炭反応におけるエ マルジョン層の役割については次章で述べる.

炉内のスラグ層高さの吹鋉時間による変化につき島田 らの研究が発表されている(1415)16). 図 5 は $170 \mathrm{t}$ 転炋に 技ける実測の結果で，スラグ層の高さとスロッピングの 関係が明確に示されている16)。

泡立ちスラグ層の高さは一般に層内におけるCOの上 昇速度すなわち脱孷速度とともに増加する ${ }^{17)}$. LANGE ${ }^{18)}$ はこのようなスラグの泡立ち現象は流動層と類似の現象 であるとして数值的な取扱いを行なつている.この場合 流動層の粒子に相当するものはスラグと粒鉄であり，こ のような粒子の密度にはスラグと粒鉄の量に态じてとつ

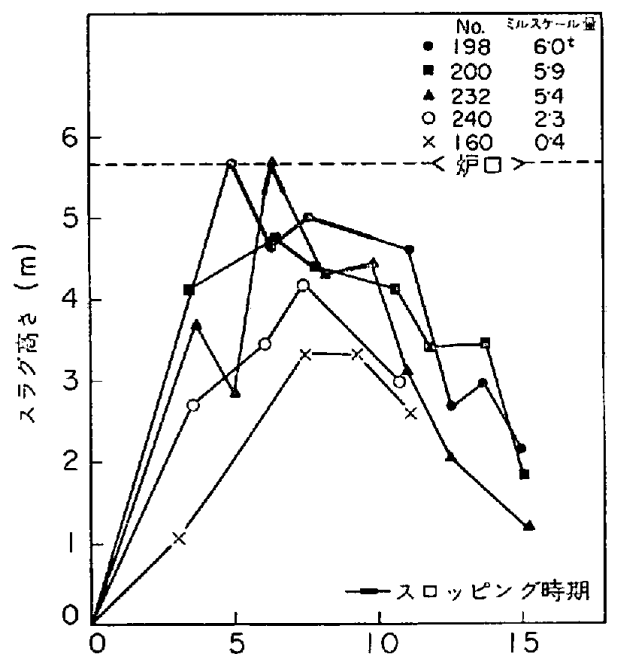

因 5 転师内スラグ高さの变化とスロッビングの関 係（立川，葛田，石橋，白石 ${ }^{(6)}$ )

た平均的な值を考えている，流動層の関係式を用いて検 討した結果，スラグ層中のCOの平均上昇速度は流動層 を考光た場合の上限と下限の䠦界速度の間にあり，粒鉄 を含むスラグ層は CO ガスにより流動化されだ状態にあ ることが加かた，したがつて，CO の生成速度がある 限度以上ではスラグの炉口からのあふれやスロッピング の現像をおこすようになり，この点で操業速度の限界が ある、種々仮定があり，疑問むあるが，一つの興味ある 見方と荅党られる。

\section{3. 浴の酸素吸収と脱炭反応}

L D 転怩内反応についてもつとも特徽的なことは吹鍊 速度が送酸速度で一義的にきまつてくることである. 図

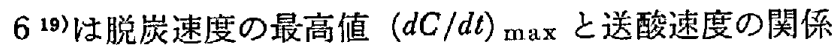
であるが，脱炭速度は送酸速度に比例して増加すること がわかる．同じことがまた図７に示されている．これは 高速吹鍊の立場から試験転㥓で行なつた系繶的研究の結

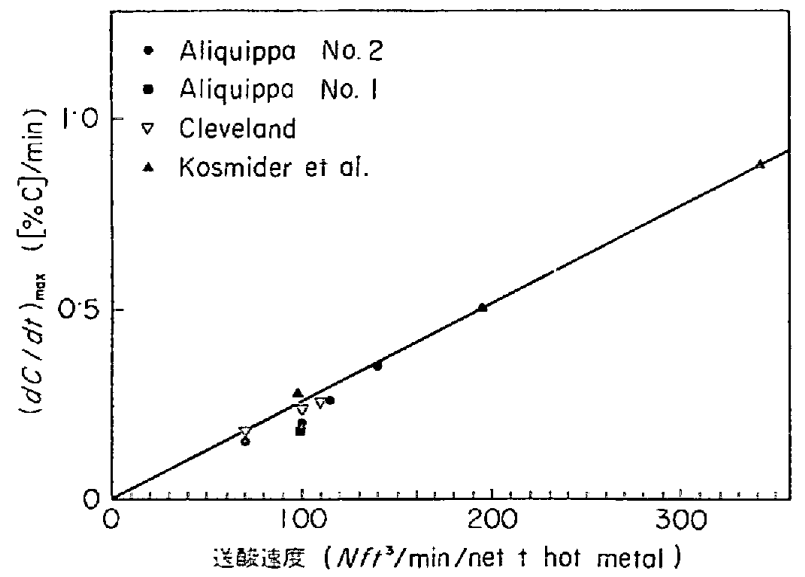

図 6 最高脱炭速度と送酸速度の関俰 (MEYER ${ }^{19)}$ ) 


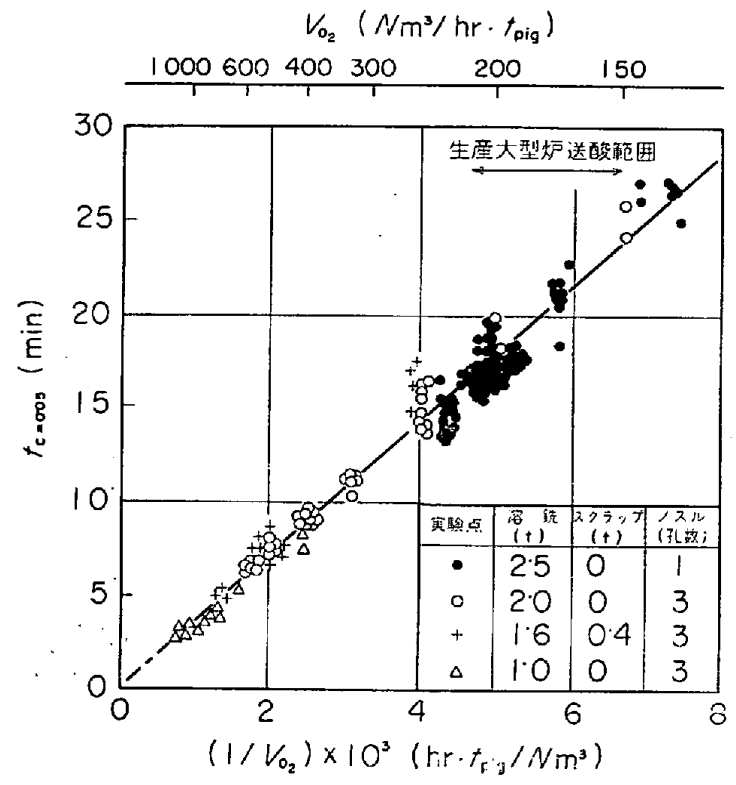

図 7 吹錬所要時間と送酸速度の関係 (手墳, 山口, 稲富 ${ }^{20)}$ )

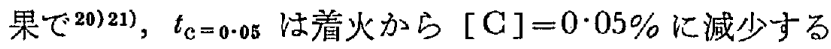
までの時間で，これが送酸速度の逆数 $1 / V_{\mathrm{O}_{2}}$ に比例する ことは，図6 と同じょうに，脱炭速度が送酸速度に比例 することを意味する。

L D 転炉の吹錬速度に関する以上の事実は, 鋼浴の酸 素吸収あるいは脱炭反応の速度に限界がまだ示されてい ないことを意味するわけで，この問題の追求は理論的実 際的にきわめて興味のあるとこるである．以下，この問 題についての従来の研究をまとめてみた。

\section{1 酸素ジェットと䤡浴の相互作用}

$\mathrm{C} ， \mathrm{Si}, \mathrm{Mn}, \mathrm{P}$ などの成分をむつ鋼浴に高速の酸素が 吹付けられたとき，酸素はどのような形で鋼浴にとらえ られるであるらか. ソ連の研究者はこれについてつぎの ような考え方を出している22) 24).

鋼浴中に空気が気泡として吹込まれる場合の浴と酸素 の反応についてつぎの 2 通りのるけ方をしたａ）送風 生力があまり大でなく，また鋼浴の温度があまり高くな く粘性のあるとき，比較的大きな気泡ができる，。この場 合，気泡中の $\mathrm{O}_{2}$ は界面にある $\mathrm{Fe}$ その他の元素のすべ て它酸化するのに十分で “酸素過剩”の状態にあり，ま た $\mathrm{Fe}$ 原子が $\mathrm{C}+\mathrm{Si}+\cdots \cdots \cdot$ 原子に比しはるかに多いため Fe の酸化が傩先しておこることになる. これに対し， b）送風生力が大であり，鋼浴が高温で流動性のよいと きは気泡は小さく分散度が大きい，このとき $\mathrm{O}_{2}$ は界面 にあるすべての元素を酸化するのには不十分で“酸素不 足”の状態にあり，鋼浴成分，酸化をきめるのは熱力学 的な親和力である。

L D転炉で酸素が鋼浴に吹き付けられるような場合に ついては以上の機構はをのままはあてはまらないが，考 え方は適用できる、すなわちLD転炉では，酸素気泡が
高度に分散することは考えられず，火点近くでは“酸索 過剩”の状態にあり，そのため $\mathrm{Fe}$ が㯪先的に酸化し， 生成された $\mathrm{FeO}$ が鐥唂あるいはスラグに運ばれ，2次 的に脱炭その他の酸化反応安起こす21)25)26).

以上のように火点に打いて酸素がまず $\mathrm{FeO}$ としてと らえられるということには速度論的に 2 つ要因が考え られる。一つは気泡界面人のCの物質移動のおくれであ り，う一つは溶鉄-FeO(l) 界面において $\mathrm{CO}$ 気泡核 生成が困難であることによる ${ }^{27) . ~}$

酸素シェットの浴表面への衝突部において，沙ェット が弱いときはくぼみの形状も簢単なものであるが，シニ ットが強くなると，粒滴の生成や気泡まきこみがおこり 23)25)26) 28) 29) 30)，これによる反応界面積の增加が高い吹鍊 速度のもとになることが考えられる。これについては次 節で述べる.

\section{2 脱宸反応の機搆}

L D 転炉内の脱炭機構について従来出されている説法 大別して, a) 火点説, b) スラグーメタルエマルション 説，およびc）粒滴脱炭説の三つになる.このうちa） の火点説では脱炭反応は主として火点近傍の限られた領 域でおこると考える，前節で述べたように，火点で酸素 が $\mathrm{FeO}$ の形でとらえられこれが 2 次的に脱炭反応に与 かるとするもので，脱炭反応の機構としてはやくから考 えられていた、しかし，この機構ではたして実際の転炉 において達成される高い吹鍊速度が説明できるかどうか 不明であつた。

ここで出されたのが，MEYER ら19)31）によるb）のス ラグーメタルエマルジョン説である.これは, 火点説に よる脱炭では反応面皘が小さく，実際における高速の吹 鍊反応をとても説明できないとして考えられたものであ る、転炉内の泡立らスラグ中には多量の粒鉄が含まれ工 マルションをつくつており，スラグー粒鉄間の界面積が きわめて大きいため，ここでもし脱炭がおこるとす机ば それが全体の脱炭に占める割合も非常に大きいことが考 えられる. MEYER らは実際の $200 \mathrm{t}$ 転炉の出鋼口から 排出されたスラグ中の粒鉄の量, 大きさ, 化学分析値を 調ベた。これから，スラグーメタルエマルショョンに含 まれているメタル粒の大きさは14〜100メッシ，その量 はメタルの全装入の 30\%またはそれ以上で，スラグーメ タル間の界面積は $50000 \mathrm{~m}^{2}$ にも達することを見いだし た. エマルジョン中の粒鉄の脱炭は $\mathrm{C}$ 拡散律速ではな く，○か゚スラグから粒鉄内にはいつて過飽和の状態にあ り，この粒鉄が $\mathrm{CO}$ 気泡や $\mathrm{CaO}$ 粒に接触した場合，あ るいは粒鉄内で突発的に $\mathrm{CO}$ 生成が抗こると考えた。す ちろえ脱炭はこのようにスラグ中で進行するほか鋼浴内 部でも進行する.この鋼浴内部の脱炭速度が吹鍊初期の スラグのない場合の脱炭速度にひとしいとすると，全吹 鍊期間を通し $2 / 3$ の れると推定される。このらにして，スラグーメタルェ 
マルジョン層の存在が物質移動の大きな界面積を与え, 高速の吹錬を可能にしていると考える.これはまたベッ セマ法その他のプロセスにおいても重要な役割をるつと している.

MEYER らの提唱した以上のスラグーメタルエマルジョ ン説はスラグ中に含まれている粒鉄に注目したもので興 昧ある見解であるが，脱炭の機楎として性多くの疑間点 がある.MEYER らの説によるとLD転炉の高い脱炭速度 はスラグの存在によりはじめて実現されることになる. しかし，これを否定するような研究がいくつかある.

Koorz ら ${ }^{32) 33)}$ は，スラグが $\mathrm{FeO}$ の濃度が低いため固 体状で反応性がほとんどないような場合でも脱炭酸素効 察は高いと述べている. またタンマン炉の実験で，スラ グと接している溶鉄に Ar を吹込んだ場合，スラグが $\mathrm{FeO}$ をかなり含み粘性が低いときは $\mathrm{CO}$ 気泡核生成が 困難であり脱炭速度はおそいとしている.これはスラグ と粒鉄との間の脱炭反応が必ずしもはやくないことを示 咹している.

赤松，佐々木 ${ }^{34)}$ は $60 \mathrm{~kg}$ のスクラップを溶かし，スラ グのない状態で吹鍊実験を行ない，さらに他の大型の炉 のデータむ含め脱炭酸素効率は図 8 のように整理される ことを見いだした。これでみると，酸素の吹き付けがあ る程度以上強い限りスラグなしでも酸素は 100\%近く脱 炭に利用されていることを示している，スラグなしで高 い脱堅酸素効率が得られることは桝井ら 28 29)の研究でも 示されており，またROTE ら ${ }^{10)}$ 女試験転师の实験で脱炭 にはとくにスラグの存在は必要ないことを示している.

OKнотSKII ${ }^{35)}$ はエマルジョン中の粒鉄とスラグの間の 脱炭反応速度を理論と実験の両面から考察している. 反 応速度を支配する過程は，粒内のCの物質移動，スラグ 側の $\mathrm{FeO}$ の拡散, および界面化学反忘の 3 つであると し，各速度式について検討した結果，粒鉄の移動および 粒の内部循環がおこるため物質移動ははやく，脱炭反応 は界面反応で律速されると推定した，実験は $1 \mathrm{t}$ の試験 転师で行ない，スラグ中の粒の大きさ，量，C濃度を求 め，脱炭反応速度を見積つた. その結果からスラグ中の 粒鉄による脱炭は全体の 10～15\% 程度であると結論し

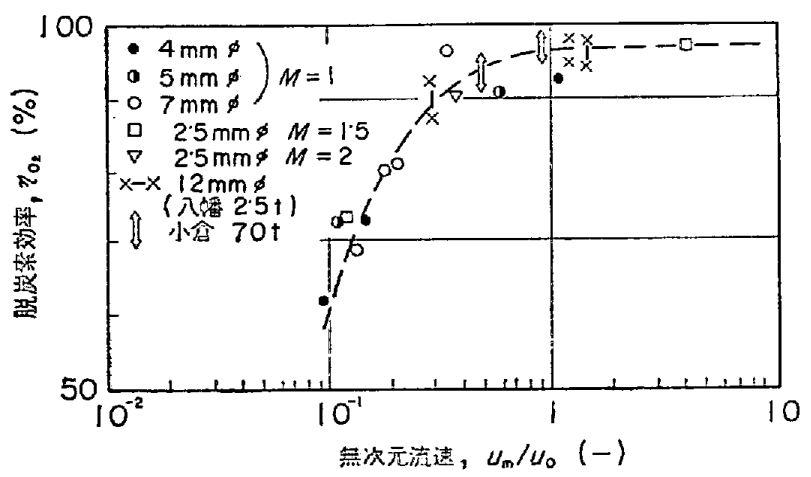

因 8 脱炭酸素勃率と無次元流速との関係 (赤松, 佐々 ${ }^{34)}$ )
た。

岡野ら ${ }^{36)}$ は転炉内の脱岸反応が火点, 龬浴内, およぴ スラグー鋼浴界面の 3 つの領域で進行するとし，それぞ れの領域における脱炭反応を表わす モデル式をつくつ た. 一方, $200 \mathrm{t}$ 転师の吹鍊中の諸成分の時間変化を調 ベ，モデル式を適用して各領域における脱炭の奇与密を 求めた，その結果吹鍊全期間を通じて火点に招ける脱炭 の割合がもつとも大きく、スラグーメタル間の反応による 脱炭は 20\% 以下であると結論している.

これらの研究はいずれもエマルション説を否定するの に十分な事実を提供している. MEYER らか゚ェマルショ ンから採取したサンプルは出鋼口から排出されたもの で，炉中のエマルション層を代表していたものかどう か，また粒鉄中の合濃度が非常に高いことから付着した スラグを完全に除去したかどうか多分に疑䦐である。

最近栘井ら ${ }^{28) 29)}$ は粒滴脱炭説を出している.この研究 は酸素シェットにより火点で大量に発生する粒滴に注目 したものである．実験は $100 \mathrm{~kg}$ の試験転炉（実験は 65 $\mathrm{kg}$ ）で行ない，粒滴の量，大きさ， C 濃度を調査し， さらにモデル実験で求められた粒滴発生の条件を適用し 検討した結果，脱炭酸素效率が 100\%になるところでは 火点脱炭 $30 \%$ ，粒滴脱炭 $70 \%$ であるとしている.（図 9）またこの場合の粒滴脱炭は火点近傍のごく狭い範囲 でのみおこるとしている.この粒滴脱炭もさきのエマル ション脱炭と同じように反応界面稓が大きいことに注目 した考え方であるが，むしろ火点説に近いとみるべきで あろう、なぜならば，粒滴発生の段階ですでに脱炭が行 なわれているとみることもできるからである.

以上のようにして，L D 転师の酸化脱炭反応はやはり 火点説により説明されると考える.しかし，この説で最 大の問題は議論があまりにも定性的であり理諭的裏付け に久ケることである. 気体酸素による脱炭反応はある面 では液体金属に対するガス吸収の問題とすみなすことが でき，著者らはモデル実験として溶融銀への酸素吸収を ガス吹き付け ${ }^{37)}$ および吹き込み ${ }^{38)}$ にり実験した。

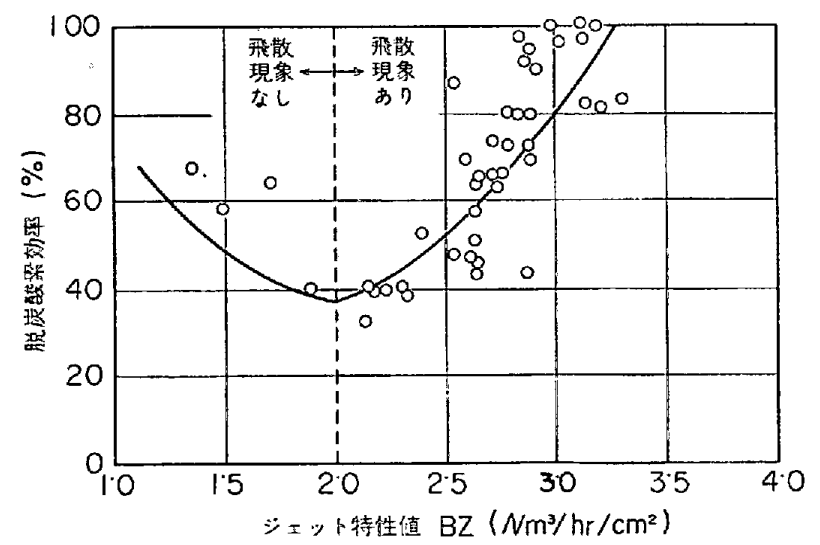

図 9 脱炭酸素効弯とジェット特坐值の関係 (姝井, WenZel, Block, STOLZENBERG ${ }^{28)}{ }^{29)}$ ) 


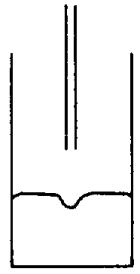

(a)

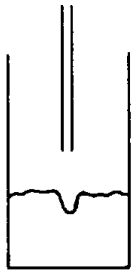

(b)

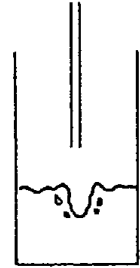

(c)

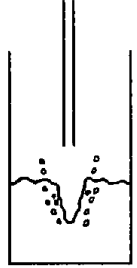

(d)
図 10 酸素ジェットによる銀浴のくぼ (松島，森 ${ }^{37)}$ )

酸素ガス吹き付け実験は, $1050^{\circ} \mathrm{C}$ において $230 \mathrm{~g}$ の 銀浴に径 $1 \mathrm{~mm}$ のアルミナノズルを通し酸素ガスを吹 き付けたものである，本実騟で，浴面の状態は酸素ガス の吹き付け条件によつて大きく異なり，これがガス吸収 速度に大きく影響することが明らかにされた，肉眼によ る浴面の観察結果は図 10 に示したように4段階にわけ られる.才なるち，a）吹き付けが弱くくぼみが安定し しいる，b）吹き付けが強くなるとくぼみの梁さは増 し，浴面には振動が生ずるか゚，この段階では浴面は安定 した状態にある，c）浴面の振動およびくほみは不安定 になり，ときにはシェットが浴内にはいりこむ，d）吹 き付けがさらに強くなると浴面の振動ははげしくなり， 気泡まきこみと飛沫現象がおこる。

溶融銀中のO濃度ははじめ时間とともに直線的に増 加するか゚，ある O濃度以上ではつぎの反応速度式で表わ される变化を示す.

$$
\begin{aligned}
& \frac{d[\% \mathrm{O}]}{d t}=k *\left(\frac{A_{0}}{V}\right)\left([\% \mathrm{O}]_{\mathrm{e}}-[\% \mathrm{O}]\right) \\
& k^{*}: \text { 見がけの速度定数 }(\mathrm{cm} / \mathrm{sec}) \\
& A_{0} \text { : 見かけのガスーメタル界面積（るつ活断 } \\
& \text { 面積）(cm) } \\
& V: \text { メル容積 }\left(\mathrm{cm}^{3}\right) \\
& {[\% \mathrm{O}]_{\mathrm{\theta}}: P_{\mathrm{O}_{2}}=1 \text { atm に対寸る平衡濃度 }}
\end{aligned}
$$

実験から $k^{*}$ を求め，これにより酸素吸収速度に対す る吹付条件の影響を評価することができる，図 11 に* とくぼみ深さLの関係を各ランス高さについて示した. ただし $L$ は計算值である. $L<0.3 \mathrm{~cm} 03$ 点は浴を㩇汼 して均一濃度に保つた場合で，これを含め $L<0.6 \sim 0.7$ $\mathrm{cm}$ における $k^{*}$ は $0.01 \sim 0.02 \mathrm{~cm} / \mathrm{sec}$ 程度の大きさで ある.この值は吹き付けを行なわず高周波誘導覞䢁銀浴 に雾囲気から酸素が吸収される場合の物質移動係数とほ ぼひしい：これはくぼみが图 10 (a)，(b) のよ5に安 定している場合で，〈ぼみそのものによる速度定数の増 加はほとえどないことを示す，一方，吹き付けが強く $L$ $>0.7 \mathrm{~cm}$ になると $k^{*}$ は急に大きくなる.これは，図 10 (c)，（d）のように，界面が乱れ，気泡まきこみや飛 沫現象がおこる場合で，このような状態になつてはじめ て吸収速度が増大し吸収勃率も高くなることがわかる。

つぎに，酸素吹き込み実験では $1000^{\circ} \mathrm{C}$ の銀浴 150

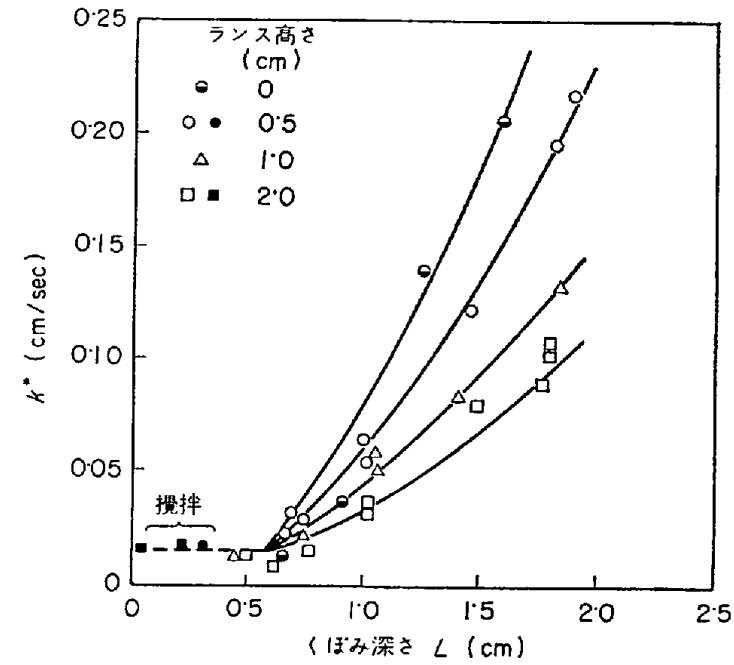

因 11 見かけの速度定数とくほみ深さの関係 (松島，森 ${ }^{37}$ )

$700 \mathrm{~g}$ 中に内径 $1 \cdot 2 \mathrm{~mm}$ の石英管ノズルより酸素を吹き 込んだ. 図 12 にO濃度と時間の関係を示す。これでわ かるように旦濃度は飽和濃度の $90 \%$ 近くまで時間とと むに直線的に増加している。ここでは酸素は $100 \%$ 近く 銀浴中に吸収され，吸収は酸素の供給速度できまる、し かし○濃度が飽和近くになると吸収速度はしだいにおそ くなる，著者らはこの問題を気泡一溶融金属間の物質移 動の問題としてとらえ, 気泡の大きさ, 上昇速度, 物質 移動係数などを考慮して容量係数を計算し，実測値との 比較検討を行なつた，図 12 の曲線は計算曲線で実験值 とよい一致を示している。これから， O濃度の時間変化 は気泡一溶融銀界面における液側の物質移動により説明 できることがわかる。

以上著者らが行なつた $2 つ の$ 実験結果を一緒にする と，吹き付けによる溶融金属のガス吸収において，吹き 付けをしだいに強くしてゆくと吹き込多と同じような吸

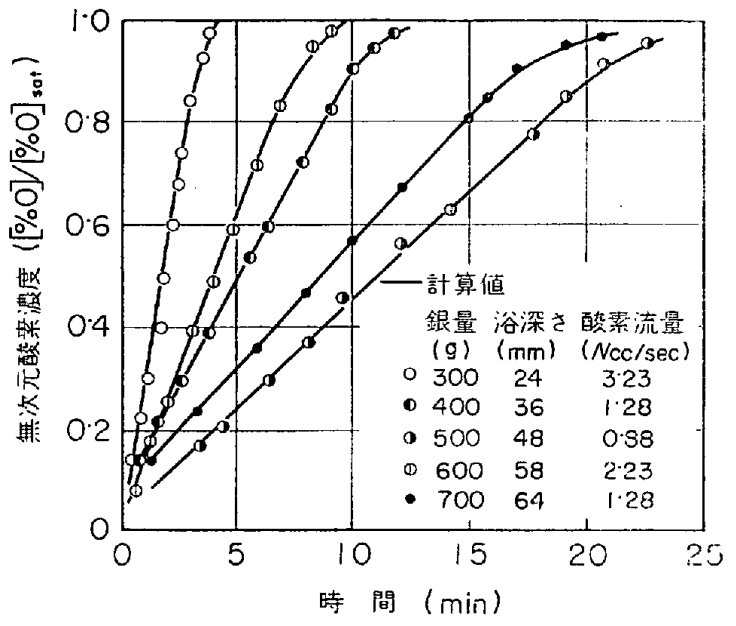

図 12 銀浴一の酸秦の吸収曲線 (森, 佐野, 菱田, 鈴木 ${ }^{38}$ ) 
収效率が 1 に近くなるような状態を想定することができ る.これ仗き付けが強く大量の気泡をきこみと飛沫現 象か゚拉こる場合である。

L D 転炉に打ける溶鋼の酸化眖炭反念む上と類似の機 構で考えられる、酸素シェットの溶銅への衝突くぼみで は図 $10(\mathrm{~d})$ のような状態がはげしく抢こり，まきこま れた気泡と粒滴が共存したような状態をとる。この場合 反応界面積が非常に大きいため，溶銅側のO物質移動速 度できまる酸素吸收速度がきわめて迅速であり, 吹き付 け酸素は $100 \%$ 近く火点付近淿打いて吸収され，これが 2 次的に脱炭反応に消費されるすのと考えられる. 前述 の火点説はこのような内容をむつもので，高い吹鍊速度 は根本的に注反应界面積が非常に大きいことによると考 えるが，スラグーメタルエマルジョン説とはまつたく異 なる機構である．さき机井らの粒滴脱炭説は火点説 のなかに含めて考えることができると述べたが，これも 上述の説明汃ら理解される。

MEYeR ら ${ }^{31} は$ は，ベッセマ法などの底欦法に拉いても スラグーメタルェマルション中の 反応が高い欦錬速度に ついて重要な役割をるつているとしているが，これは実 際には気泡一溶鋼間の大きな物質移動速度によるもので ある。

\section{4. スラグー鋼浴間反応}

転炖内の反応系は 前章で述べたガスー鋼浴間反応と, 脱燐反応で代表されるスラグー鋼浴間反応が複雑にから みあつたものである。転炉内では脱炭が迅速に進行する とともにスラグ-銅浴間反応もまた迅速に進行すること が要請され，実際にもスラグと鋼浴の間はかなり平衡に 近い状態であるとされている

転炉内におけるスラグ-鋼穃間反応は回分式反応系と みなすことができ，両相が密に接触した状態で反応が進 行してゆく．したがつて反応の進行をむつとも大きく支 配するのはスラグー溶鉄間の平衡論的因子であるが，こ

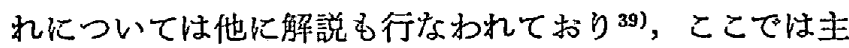
として速度論的な問題をとりあけ゚る。

\section{$4 \cdot 1$ スラグ-溶鉄間物質移動のモデル}

スラグ-溶鉄間反応のうち高炉型反応のように CO 発 生を伴う反応は界面反応の速度が総括反応の速度を大き く支配寸るが40)，製鋼反応の場合恃界面反応の速度はは やく物質移動律速で，界面は平衡にあると考えられる ${ }^{41) . ~}$ 以下この立場でスラグ-溶鉄間の反応速度を数式モデル により検討する42).

製鋼におけるスラグー溶鉄間反応はいくつかの反応が 並列しておてる同時反応系で, 各反応は相互に影響を及 ぼしあつて進行する．したがつて，ある一つの反応をと りあけ゚た場合，これが他とは独立に平衡を保ちながら進 行するということは理論的にはありえないと考劣られ る.たとえぱ Mn 反応は

$$
\mathrm{Mn}+\mathrm{FeO}(\mathrm{slag})=\mathrm{Fe}(1)+\mathrm{MnO}(\text { slag })
$$

で表わされるが，実際にはこのほかにスラグから溶鉄へ の○の移動の反応

$$
\mathrm{FeO}(\text { slag })=\mathrm{Fe}(\mathrm{l})+\underline{\mathrm{O}}
$$

が同時に進行する.したがつて (2)式の Mn 反応の進行

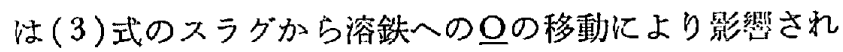
るはずである。

溶鉄およびスラグ中の各成分の淃度を $C^{\prime}, C^{\prime \prime}(\mathrm{mol} /$ $\left.\mathrm{cm}^{3}\right)$ ，界面における濃度を $C^{\prime}{ }_{i}, C_{i}{ }^{\prime \prime}\left(\mathrm{mol} / \mathrm{cm}^{3}\right)$, 物 質移動係数を $k^{\prime} ， k^{\prime \prime}(\mathrm{cm} / \mathrm{sec})$ で表わし，界面皘を $A$ $\left(\mathrm{cm}^{2}\right)$ とする. 溶鉄中の $\mathrm{Fe}$ の移動は律速段階になら ないむのと考えられるので除外し， $\mathrm{Mn}, \mathrm{Mn}^{2+}, \mathrm{Fe}^{2+}$, Oについて物質移動速度》の式を与える。これに界面平 衡の条件

$$
m_{1}=C^{\prime \prime} \mathrm{Mn}_{\mathrm{i}} / C^{\prime} \mathrm{Mn}_{\mathrm{i}} \cdot C^{\prime \prime} \mathrm{Fe}_{\mathrm{e}_{1}}, m_{2}=C^{\prime} \mathrm{O}_{\mathrm{i}} / C^{\prime \prime} \mathrm{Fe}_{\mathrm{i}}
$$

および反応の定常進行の条件

$$
\dot{n}_{\mathrm{Mn}}=\dot{n}_{\mathrm{Mn}^{2+}}=\dot{n}_{\mathrm{Mn}}, \dot{n}_{\mathrm{Fe}^{2+}}=\dot{n}_{\mathrm{Mn}}+\dot{n}_{\mathrm{O}} \cdots \text { (6) (7) }
$$

を考虑し，Mnの移動速度式としてつぎの式が得られる。

$$
\begin{aligned}
& \dot{n}_{\mathrm{Mn}} / A=k^{\prime \prime}{ }_{\mathrm{Mn}}\left(\xi-\sqrt{\left.\xi^{2}+4 \eta\right) / 2}\right. \\
& \xi=\frac{k_{\mathrm{Mn}}^{\prime} k_{\mathrm{Fe}}^{\prime \prime}}{k^{\prime \prime}{ }_{\mathrm{Mn}^{2}}}\left\{\frac{k_{\mathrm{Mn}}^{\prime \prime}}{k^{\prime \prime}{ }_{\mathrm{Fe}}} C_{\mathrm{Mn}}^{\prime}+\frac{k_{\mathrm{Mn}}^{\prime \prime}}{k_{\mathrm{Mn}}^{\prime}}\left(C^{\prime \prime}{ }_{\mathrm{Fe}}+\frac{k_{\mathrm{O}}^{\prime}}{k_{\mathrm{Fe}}^{\prime \prime}} C_{\mathrm{O}}^{\prime}\right)\right. \\
& \left.+\left(\frac{1}{m_{1}}+\frac{k_{\mathrm{O}}^{\prime}}{k_{\mathrm{Fe}}} \frac{m_{2}}{m_{1}}\right)\right\} \\
& \eta=k_{\mathrm{Mn}}^{\prime \prime} k_{\mathrm{Mn}^{2}}^{\prime \prime}\left\{\left(\frac{C_{\mathrm{Mn}}^{\prime \prime}}{m_{1}}-C_{\mathrm{Mn}}^{\prime} C_{\mathrm{Fe}}^{\prime \prime}\right)\right. \\
& \left.+\frac{k_{\mathrm{O}}^{\prime}}{k_{\mathrm{F} \Theta}}\left(\frac{m_{2}}{m_{1}} C^{\prime \prime}{ }_{\mathrm{Mn}}-C^{\prime}{ }_{\mathrm{Mn}} C^{\prime}{ }_{\mathrm{o}}\right)\right\}
\end{aligned}
$$

(8) 〜 (10) 式において同時反応の影響は $(10)$ 式右辺の 第 2 項で表わされる. この項が0のとき，すなわち(3) 式の同時反応を考慮しない場合, $\mathrm{Mn}$ 唯 $(\mathrm{FeO})$ で酸化 される $\left(\dot{\mathrm{Mn}}_{\mathrm{n}} / A>0\right)$ のは $(8),(10)$ 式で $\eta<0$, すなわ 方

$$
C^{\prime \prime}{ }_{\mathrm{Mn}} / m_{1}-C^{\prime}{ }_{\mathrm{Mn}} C_{\mathrm{Fe}}<0
$$

の場合である。しかし同時反㦄孛慮した場合は (8)， (10)式からわかるように，(11) 式が満足されても必ずし む $く<0$ にはならない，それは(10)式の右辺第 2 項

$$
\left(k_{\mathrm{O}}^{\prime} / k^{\prime \prime}{ }_{\mathrm{Fe}}\right)\left\{\left(m_{2} / m_{1}\right) C^{\prime \prime}{ }_{\mathrm{Mn}}-C_{\mathrm{Mn}}{ }^{\prime} C_{\mathrm{O}}\right\}
$$

の值がある程度以上大きくなり， $\eta>0$ したがつて $\dot{n} / A$ く0 になるような場合むありうるからである。これは (2) 式の反応のみに関する限り $\mathrm{Mn}$ はスラグ中の $\mathrm{FeO}$ で酸化されるような条件であつても，場合により Mnは スラグから還元される可能性のあることを示すものであ る.このような可能性は $k_{\mathrm{O}} / k^{\prime \prime}{ }_{\mathrm{Fe}}$ が大きく溶鋼中のO濃 度が低く保たれる場合に現われるが，これ哇実際の製鋼 反応において，合がスラグから鋼浴内に供給され鋼浴内 において脱炭反応に消費されるという反応が迅速におこ つている場合に相当する.

以上の計算からいえることは，(3)式の反応が平衡状 
態から大きく離れて迅速に進行している場合，(2)式の 反応のみの平衡は理論的には考えられないということで ある. 1 例として図 13 亿転炬欦錬中の鋼浴内の $\mathrm{Mn}$ 濃 度》およびスラグとの平衡濃度を示す. 実際の $\mathrm{Mn}$ 濃度 はスラグとの平衡濃度にかなり近い值で変化してゆく が，平衡濃度よりは若千高いところにある。 Mn 濃度が 時間とともに増加してゅく場合にこのように実際の濃度 が平衡値より高いのは上述の数式モデルで表わされる同 時反忘進行の 現象が 実際に示されたものとも考えられ る.しかし，現状で直ちにこのような結諭を出すことに は問題がある．それは，熱力学的数值 ${ }^{43)}$ の信頼性が不明 であり，また炉内のスラグおよび鋼浴の濃度の均一性に む検討の余地が残されているからである.

\section{2 スラグー溶鉄間物質移動の機搆}

以上の数式モデルにおいては溶鉄およびスラグ側の境 膜物質移動係数は単なるパラメータであるとして取扱つ たが，実際にスラグー溶鉄間の反応速度を検討するため には物質移動係数の值を知ることが必要である。ささらに 総括反応速度 $\dot{i}=k A \Delta C$ ( $k$ : 総括物質移動速度, $A$ : 界 面積, $\Delta C$ : driving force) からわかるように反応速度は 界面積 $A$ にも関係し， し加も実際の場合にはこの $k$ と $A$ を分離して求めることはきわめて 困難である場合が多 い. 化学工学では，これを一緒にして容量俰数 $k A$ とし た扱いむなされている。しかし，これはあまりにも経験 的でありすぎ，現象の解明にはやはり物質移動の機構と 結びついた物質移動保数の值を知りたい。

実際操業に执いては スラク゚-鋼浴間界面は脱炭反応に よる $\mathrm{CO}$ 気泡通過で覺汼され，これにより物質移動が 促進されるが，RICHARDSON ら (1)44)はこのような系につ いてモデル実験を行なつている．モデルとして，溶鋼に は $\mathrm{Zn}$ を合む $\mathrm{Hg}$ ，スラグには水溶液を用い，つぎの反 応を行なわせている.

$$
\begin{aligned}
& 2[\mathrm{In}]+3\left(\mathrm{Hg}_{2}{ }^{2+}\right)=2\left(\mathrm{In}^{3+}\right)+6[\mathrm{Hg}] \\
& {[\mathrm{In}]+3\left(\mathrm{Fe}^{3+}\right)=\left(\mathrm{In}^{3+}\right)+3\left(\mathrm{Fe}^{2+}\right)}
\end{aligned}
$$

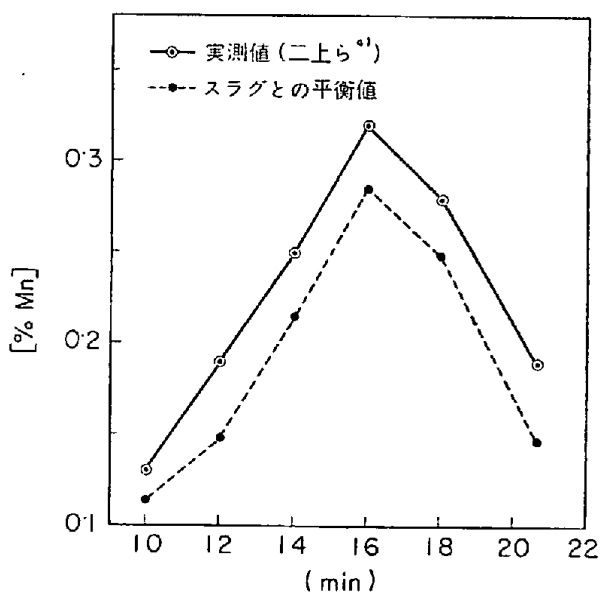

図 13 転炉鋼浴内マンガン浱度の变化 (森, 野村, 福原 ${ }^{42)}$ )
これらの反応の平衡はいちじるしく右辺にかたよって おり，初濃度を変えることによりメタル側移動律速およ び水溶液側移動律速が容易に実現される．たとえば(13) 反応については図 14 の濃度分布およびつぎの物質移動 速度式が与えられる。

$$
\begin{aligned}
& \times \text { タル側移動律速 }-\frac{d[\mathrm{In}]}{d t}=k_{\mathrm{M}} A\left[\mathrm{I}_{\mathrm{n}}\right] \cdots \cdots \\
& \text { 水溶液移動律速 }-\frac{d\left(\mathrm{Fe}^{3+}\right)}{d t}=k_{\mathrm{w}} A\left(\mathrm{Fe}^{3+}\right) \cdots
\end{aligned}
$$

実験結果から，(14)，(15)式が適用されそれぞれの律 速過程の存在することが明確に示されたが，これは実際 のスラグ-鋼浴間反応の速度考考えるときの確かな根拠 を与えるものである.

RICHARDSON らは 1〜2cc の小さい気泡で頻度 50〜 $300 / \mathrm{min}$ の場合 ${ }^{41)}$ と，3〜47cc の大きい気泡で頻度 12 〜24/min の場合 ${ }^{44)}$ について実験し，これから溶銅およ びスラグの物質移動保数 $k_{\mathrm{M}} ， k_{\mathrm{s} 1}$ を表わすむのとしてつ ぎの式を与えている.

$$
\begin{aligned}
& \frac{\dot{n}}{A} \frac{1}{K}=\frac{\dot{n}}{A}\left(\frac{1}{k_{\mathrm{M}}}+\frac{m}{k_{\mathrm{sl}}}\right)=\left(C_{\mathrm{M}}-m C_{\mathrm{sl}}\right) \\
& k_{\mathrm{S} 1} \propto D_{\mathrm{si}}^{0.27} \nu_{81}^{-0.27} f^{0.8} d^{1 \cdot 26} \\
& k_{\mathrm{M}} \propto D_{\mathrm{M}}^{0 \cdot 3} \nu_{\mathrm{M}}^{-0.3} f^{0 \cdot 33} d^{1 \cdot 25} \\
& D_{\mathrm{M}}, D_{\mathrm{s} 1} \text { : メタル，スラグ中の拡散係数 } \\
& \nu_{\mathrm{M}}, \nu_{\mathrm{sl}}: \times タ ル \text {, スラグの動粘性係数 } \\
& f: \text { 気泡の界面通過の頻度 } \\
& d: \text { 気泡径 }
\end{aligned}
$$

この式を平炉でスラグ酸化により脱炭がおこる場合に 適用した. この場合, 気泡の大きさ $d$ および頻度 $f$ はモ デル実験におけるよりも大きいので， $d, f$ には外捙值 を代入した．その結果物質移動俰数として $k_{\mathrm{M}}=0.0174$ $\mathrm{cm} / \mathrm{sec}, k_{\mathrm{sl}}=0.0081 \mathrm{~cm} / \mathrm{sec}, K=0.017 \mathrm{~cm} / \mathrm{sec}$ が計算

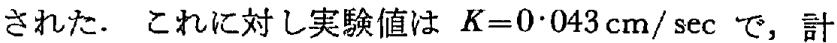
算值は実験值の約 40\%でかなり小さい。これは，モデ ル実験からの単なる外挿では実際の現像は説明できず, 実際には気泡が大きく頻度が高くなつた場合に，メタル

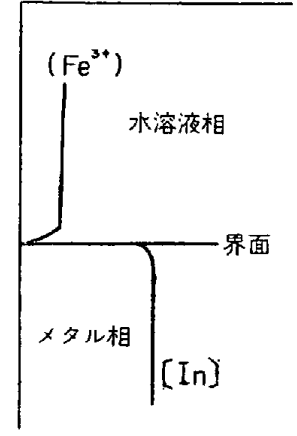

（a）水溶液相側律速 (b) メタル相側律迹

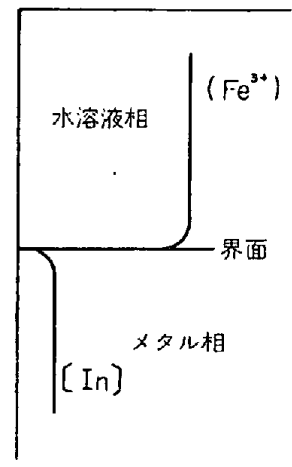

図 14 水溶液ーフマルガム反応系に打ける賑度分布 (Porter, Richardson, Subramanian ${ }^{41}$ )) 
粒がスラグ中に混入し，これによる界面積の増加があ り，その分だけ見かけ上物質移動係数は大きくなつたた めと考党られる.

RICHARDSOM らは，上述のモデル実験で父泡通過にと むなう界面の乱れの状態を高速度カメラで撮影し, 気泡 か゚メタルから水溶液相にはいるとき，気泡上面にメタル が膜となつてメタル本体を離れ，これが水溶液相にメタ ル粒を与えることを観察している。しかしこのような観 察結果を物質移動速度式の中に定量化するまでには至つ ていない，スラグー溶鉄間の物質移動係数，あるいは容 量係数をきめる機構を究明し，これを定量化することは 理論的に興味あるのみならず，実除問題を検討するのに も重要である.

前章でスラグ中のメタル粒の存在によるいわゆるスラ グーメタルエマルジョン説を述ベた。これは高速の脱炭 反応を説明する理論としては疑問の多いものであつた が，いまのスラグー鋼浴間反応については十分考慮する 必要のあることがわかる. BARDENHEUER ら45) および TRENTINI46)は，実際にLD 転怩においてスラグ中のメタ ル粒か゚，スラグー溶鋼間の反応速度を 促進するうえで大 きな役割を果たしていると述べている.

\section{3 脱燐反応}

脱燐反応は転师内におけるスラグー鋼浴間反灾のむつ とも重要な反応である. 脱燐反心の機構については定性 的には統一された考え方が出されている，㒰が酸化され る反応としてつぎの 2 つがある。

$$
\begin{aligned}
& 2 \underline{\mathrm{P}}+5 \underline{\mathrm{O}}=\left(\mathrm{P}_{2} \mathrm{O}_{5}\right) \\
& 2 \underline{\mathrm{P}}+5(\mathrm{FeO})=\left(\mathrm{P}_{2} \mathrm{O}_{5}\right)+5 \mathrm{Fe}
\end{aligned}
$$

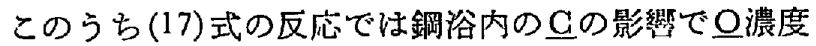
を高くすることができず，脱燐はむつぱら(18)式のスラ グー鋼浴内反応として進行する.この場合，スラグが熟 成した $\mathrm{P}_{2} \mathrm{O}_{5}$ の活量係数を低く保持できるるのであるこ とか゚条件で，転灯ではこのような条件を与えればかなり 高い唇度のところでる脱燐を優先的に進行させること ができる.ここでーつの問題は，スラグー鋼浴間ではこ のはか

$$
\mathrm{C}+(\mathrm{FeO})=\mathrm{Fe}+\mathrm{CO}
$$

がおこる可能性がある.この反応がもし(18)式の反念と 同じ場所で進行するとすれば，自由エネルギーの相違か らタて (19)式の反応が優先的に進行してしまうことにな る. しかしこの (19) 式の反応は普通 $\mathrm{CO}$ 気泡核発生の障 䅞があるためスラグー鋼浴間界面ではおこりにくく，実 際には(18)式の反応が優先的に進行するわけである。高 炭素龬の溶製において脱燐反応を優先的に進行させるた め，(18)と (19)式の競争反応の進行する機構について十 分に検討することが重要と考える.

以上のように脱燐反応はスラグー銅浴間反応として進 行する以上, 平衡にどのくらい近い状態で進行するかの 検討は脱燐の限界，最適条件を知るうえで欠かせない。
脱燐平衡については従来多くの研究が行なわれてきた が，最近石黒ら 47) (8)はこれらの基礎研究を広範囲に調査 し, 実際の脱粼反応の解析のためには TuRkDOCAN, PEARSON49)の式が最適であることを述べている.

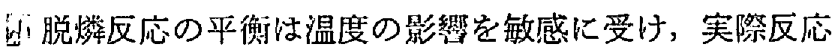
の解析にあたり炣内の盜度に十分に注意する必要があ る. 前述のようにスラグ層の温度はメタル層温度よりも 高い，反応が進行才るのは界面であり，メタルの熱伝導 度はスラグに比べかなり大きいことから，温度としては メタルの温度をとる必要のあることが推定される.図 15 は石黑 548肪 TURKDOGAN, PEARSON の式を用いて計算 した結果である、これでわかるように，スラグ温度をと つた場合に計算される卫濃度の平衡值は実測の結果より 不当に高い值であるが，メタル温度をもとにした值は実 測值をよく説明し，メタル愠度をとることの妥当性を示 している.すなわち，吹鍊中の邑は初期を除いてスラグ 一溶鉄間の脱燐平衡值によく追従して变化していること がわかる. とくに中期の $\mathrm{FeO}$ 減少，温度の増加により P漉度が増加する場合の平衡值と実測值が一致すること は興味深い，これからみると，脱燐の達成度をあげるた あに最適のスラグ組成を選ぶことの重要性がわかる。

石黒ら ${ }^{48}$ はさらにスラグエマルション層中で脱燐が進 行寸る可能性について検討し，粒鉄のスラグ層中での滞 留時間が比較的長く還流鉄量が少ないこと，および脱燐 はメタル層の温度で支配されるとした方が合理的である ことからみて，スラグエマルション層の奇与は少ないと している.

以上石黒らの研究を中心に述べたが，脱燐平衡につい ての従来の基礎研究には温度の均一性, 測温法に問題が あり，信頼性の高いデータを得るためさらに精度よい測 定が必要であるとされている60)，また脱燐の機構につい ても，スラグエマルジョン層の役割はあまり大きくない とする石黒らの見解は 4-2で述べた機構と多少異なると

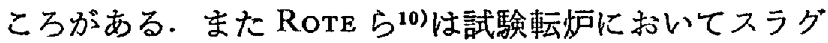
がよく熟成されたものであれば，soft blowよりも hard

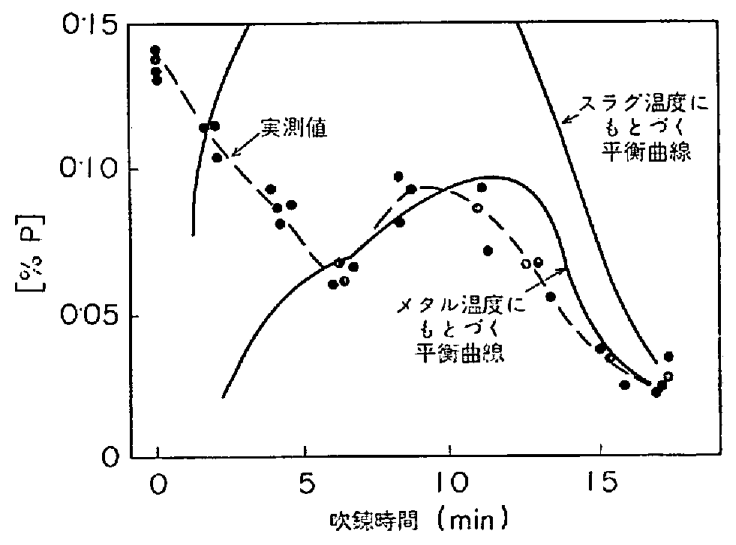

図 15 転师吹鍊中の齐の举動 (石黒，宮下，根和 ${ }^{48)}$ ) 
blow の方が脱燐がよりはやく進行することを見いだし， この理由として，強いジェットが大量の酸化された粒鉄 をスラグ中に吹きあげるからであるとしている，このよ うにスラグー溶鉄間反応における粒鉄の役割については なお検討の必要がある。

\section{5. 結言}

本稿においてはLD転师内でおこつている重要な現象 をとりあげ，とくに転炉の高速吹鍊の機棈につき徉来の 交献を整理し一つの見解にまとぬてみた．転炉内の反応 については，本稿で述べた脱炭脱粼反応のほか，脱硫， 脱空，スラグの状態図，スクラップの溶解など論ずべき 問題も多いが，筆者はこの方面のデータの持ちあるせも なく，本稿ではこれらの問題には一切ふれなかつた。

L D転炉製鋼に関する基礎研究は学会などにおける発 表からもおかるように最近かなり不活発になつてきてお り，それなりの理由は考えられる。しかし転炉製鋼法に おける理念や矛盾点の追求には常に最大の関心を払つて ゆく必要があると考える. 最近大きな話題をよんでいる Q-BOP 法の登場を思うときこの感を深くする.

\section{文献}

l) R. D. WAlker and D. Anderson: Iron Steel, 45(1972), p. 271

2 ) R. D. WAlker and $D$. Anderson: Iron Steel, 45(1972), p. 403

3 ) $R$. D. Walker and $D$. Anderson: Iron Steel, 45 (1972), p. 497

4 ）二上爱，松田一敏，小谷野敬之，安居孝司：鉄と 鋼，52(1969)，p. 1142

\$5) 浅井滋生，鞭厡：鉄と鋼，55(1969)，p. 122

6 ) 三輪守, 浅井滋生, 鞭晸：鉄と鋼，56(1970), p. 1677

7 ) R. A. Fline, R. D. Pehlke, D. R. Glass and P. O. Hays: Trans. Met. Soc. AIME, 239 (1967), p. 1776

8）松下, 盛, 不破, 館, 森, 瀬川：治金物理化学, (1970)，p. 297 [丸蹇]

9 ) 伊東修三, 鞭竿：鉄と銅，55(1969)，p. 1152

10) F. E. Rote and R. A. Flinn: Met. Trans., 3 (1972), p. 1373

11) J. Chipman: 日本金属学会会報, 12(1973), p. 367

12) 池田隆果，丸川雄浄：鉄と鋼，57(1971) 4, p. 263

13) P. Kozakevitch: J. Metals, 21 (1969) July, p. 57

14）島田道彦，石橋政衛，立川正涁：鉄と鋼，54 (1968) 10, p. 110

15）立川正彬，島田道彦，石橋正衛，白石惟光：鉄と 鋼，55(1969) 3，p. 92

16）立川正涁，島田道彦，石橋正衛，白石惟光：鉄と 鋼，56(1970) 4, p. 72
17) A. I. Tokovol, A. I. Stroganov and D. Ya. Povolotskil: Steel in the USSR, (1972) Feb., p. 116

18) $K$. W. Lange and $H$. Ress: Arch. Eisenhüttenw., 43(1972), p. 539

19) H.W. MEYER: JISI, 207 (1969), p. 781

20）手墳誠，山口紘，稲富実：鉄と鋼，56(1970) 4, p. 74

21）渡辺司郎，山口紘，手墳誠，一戸正良：鉄と鋼， $57(1971) 4$, p. 259

22) V. I. Yavoiskil and $A . F$. VishKarev: Izv. VUZav, Cher. Met., (1960) 5, p. 39

23) L. M. YeFIMOV: 第 4 回日ソ製鋼物理化学シンポ ジウム (1973)

24）ヘ・イ・ヤボイスキー：鎯製鍊過程の理論 (1967), 荻野, 森, 大森, 郡司共訳, p. 81 [日 本学術振興会]

25) E. E. Merker, V. P. Luzgin and $V . I$. YAvorSkII: Steel in the USSR, (1972) Sep., p. 698

26) $V . B$. Okhotskil and $A . G$. Chernyatevich: Steel in the USSR, (1972) Oct., p. 799

27) $R$. S. Kaplan and $W . O$. Philbrook: Met. Trans., 3(1972), p. 483

28) 椾井明, $W$. WENZEL and $F . R$. BLOCK: 鉄と鋼, $57(1971) 11$, p. 62

29) $F$. $R$. Block, $A$. Masui and $G$. Stolzenberg: Arch. Eisenhüttenw., 44(1973), p. 357

30) $P$. Kozakevitch: Kinetik metallurgischer Vorgänge bei der Stahlherstellung, hrsg. von $W$. Dahl, $K$. $W$. Lange, u. $D$. PapamanteLlos, (1972), p. 538 [Verlag Stahleisen]

31) $H$. Meyer, $W . F$. Porter, G. C. Smith and J. Szekely: J. Metals, 20(1968) July, p. 35

32) T. Kootz and A. Altceld: Thyssenforschung, $2(1970) 4$, p. 121

33) $T$. Kootz and $A$. Altgeld: Proceedings ICSTIS, Suppl. Trans. ISIJ, 11 (1971), p. 527

34）赤松径一，佐々木恵一：鉄と鋼，56(1970) 4, p. 67

35) V. B. Oкнотsкu: Izv. VUZav, Gher. Met., (1973) 6, p. 48

36) 岡野忍, 松野淳一, 大井浩, 越川隆雄: 鉄と鋼, 57 (1971) 4, p. 271

37）松島美継，森一美：鉄と鋼，57 (1971)，p. 1636

38）森一美，佐野正道，菱田護，鈴木鼎：鉄と鋼，55 (1969)， p. 1142

39）川合保治，森克已：鉄と鋼，58(1972)， p. 932

40) 芦塚正博, 德田昌則, 大谷正康: 鉄と鋼, 54 (1968), p. 1437

4l) $W . F$. Porter, F. D. Richardson and $K . N$. Subramantan: Heat and Mass Transfer in Process Metallurgy, ed. by $A . W . D$. Hills, (1967), p. 79 [Institution of Mining and Metallurgy] 
42）森一美，野村宏之，㮔原浩：学振 19 委 9248，反 応 297 , 昭和 46 年 1 月

43) J. F. Elliott and $F$. W. Luerssen: J. Metals, 7 (1955), p. 1129

44) $K . N$. Subramanian and $F . D$. Richardoson: JISI, 206 (1968), p. 576

45) $F$. Bardenheuer, $H$. von ENde and $K$. $G$. Speith: Blast Furn. Steel Pl., 58(1970), p. 401

46) B. Trentini: Trans. Met. Soc. AIME, 242
(1968)， p. 2377

47) 石黒守幸, 大久保益太，尾関昭三，若林専三: 鉄と鋼，56(1970) 4，p.71

48）石黑守幸, 宮下芳雄, 根本秀太郎：鉄と鋦，57 (1971) 4, p. 267

49) E. T. Turkdogan and J. Pearson: JISI, 153 (1953), p. 398

50) 森一美：学振19委 9376 , 反応 313 , 昭和 47 年 1 月 